\title{
A comparative investigation into the changing use of shopping malls in Germany and South Africa
}

\author{
Roger B Mason \\ Department of Marketing and Retail Management \\ Durban University of Technology, South Africa \\ Thomas Dobbelstein \\ Baden-Württemberg Cooperative State University, Ravensburg, Germany \\ Department of Marketing and Retail Management \\ Durban University of Technology, South Africa \\ Karen M Corbishley \\ Department of Marketing and Retail Management \\ Durban University of Technology, South Africa
}

\section{Keywords}

Malls; shopping centre; shoppertainment; shopping experience; super malls; mall patronage; retailing

\begin{abstract}
Based on the decline in development of new, and use of existing, shopping malls that is happening in the USA due mainly, it seems, to e-shopping, a comparative study was conducted to investigate perceptions of shopping malls and their use in Germany (a developed country) and South Africa (a developing country). Are attitudes towards mall shopping changing, or are there other factors influencing changes in mall shopping, e.g. increase in e-shopping, lack of security (especially effect of crime in South Africa), preference for localised shopping, etc.?

A questionnaire was developed from the literature and distributed via e-mail to a comprehensive database of consumers, collecting a pre-set, socio-demographic quota sample from the defined target groups. The resultant data was analysed using relevant descriptive, inferential and multivariate statistics to identify the importance of the various factors.

The main finding was that South African consumers are increasingly using shopping malls, whereas German consumers are using malls slightly less than they did 2 to 3 years ago. South Africans would like to see better entertainment and unique experiences in malls, while Germans would like to see malls developing a stronger identity, integrating themselves more into their communities and acting for the good of the community they serve.
\end{abstract}

Corresponding author: Roger B Mason

Email addresses for the corresponding author: rogerm@dut.ac.za

First submission received: $18^{\text {th }}$ March 2019

Revised submission received: $5^{\text {th }}$ April 2019

Accepted: $20^{\text {th }}$ April 2019

\section{Introduction}

During 2017, 8600 stores were expected to close in the USA (Sanburn, 2017). By 2023, half the 1200 malls in the USA are expected to close according to Rushe (2017), while Credit Suisse suggest a more conservative 20-25\% of closures (Isidore, 2017). Calvo-Porral and Lévy-Mangin (2019) concur stating that the shopping mall format is reaching maturity and along with the rise in e-retailing (Guimarães 2019) and economic downturns, resulting in lower profits, declines are inevitable. Changes in demographics (millennials more likely to shop online), shifts in spending patterns and the fact that the USA is "extremely over-retailed" with too many malls (Kuroski, 2015; Thompson, 2017) further explain this decline. 
For example, USA has about 23.5 square feet of retail space per person, compared with 16.4 square feet in Canada, about 15 square feet in Germany, 11.1 square feet in Australia, and only 2 to 4 square feet in South Africa (Peterson, 2017; Lück \& Jahn, 2017; Retail Trends: A Look at South Africa \& Others, 2017; SACSC, 2018). However, it could be argued that the current decline is merely a natural market correction due to such over production of malls (Lück \& Jahn, 2017).

According to Kolf (2017) a similar picture is emerging in Germany with both foot traffic and sales declining. In 2017 only one new mall opened compared to 3 in 2016 and an average of 10 per year over the past decade, with planned new malls being cancelled. However, no large shopping malls appear to have been closed (Lück \& Jahn, 2017). In South Africa, shopping malls have also experienced a decline in foot traffic (News24Wire, 2017), with many malls having vacancies (Tshandu, 2017) and new mall development declining (Cokayne, 2016). However, like Germany it does not appear as if South Africa is experiencing the "retail apocalypse" (Peterson, 2017; Thompson, 2017) being experienced in the USA.

The question is whether this is a unique American problem, or is it happening in other developed, and developing, nations? And if it is happening, are the reasons the same, or different. Although this may be an environmental change that individual stores cannot avoid, understanding why it is happening, and the causes, may enable retailers to act to slow it down, or to avoid the worst impacts. Furthermore, better understanding could give mall owners and management direction on ways to ensure that their mall is not the one that closes.

Therefore, the objectives of this study are:

- To identify consumers' attitudes towards malls and mall shopping in Germany (a developed country) and South Africa (a developing country)

- To identify the trend of mall shopping (increasing, static, declining) in these countries

- To identify consumers' reasons for not shopping in malls as much as they did in the past, if mall shopping is declining

- To identify, according to consumers, the things that the more successful malls do that encourage consumers to continue to shop there.

\section{Literature review}

A shopping mall can be described as a conglomeration of stores connected by means of walkways so that customers can move easily from store to store. Shopping malls are differentiated from other options such as freestanding stores, strip centres, the high street, e-retailing and other various marketplaces through their mixture of stores on offer, the safe and secure controlled environment and the possible inclusion of leisure activities such as food courts and entertainment (Kushwaha, Ubeja \& Chatterjee 2017). The main objective of most malls is the "one-stop shop" with shopping malls being managed and marketed as one offering (Narahari \& Kuvad 2017; Jooste 2016).

In recent years, shopping malls have been experiencing intense competition. As a result, Larsen, Shelton and Wright (2015) highlight the need for the management of shopping malls to understand what drives various customer attitudes and hence sales towards them. Pressure has been placed on aging shopping centres to renovate and to come up with new concepts in order to still attract their existing customer base (Anselmsson 2016). Literature on the demise of shopping malls focuses mainly on developed countries, especially the USA.

According to Hinson et al. (in Jooste 2016) developing countries, of which South Africa is one, are noting growth in the development of shopping malls. This contributes economically to the country. According to Prinsloo (2018) an increase in retail sales from R939 billion to more than R1 trillion was reflected in South Africa in 2017. Shopping centre sales were believed to contribute $65 \%$ towards this figure which amounts to a figure of R650 billion. However, according to Jooste (2016), although spending has increased in shopping malls, it is still imperative that both mall management and retailers invest in the improvement of their offering so that customers maintain positive attitudes to malls and that malls continue to be perceived as attractive and enjoyable places to shop. 


\subsection{Attitudes and perceptions towards Mall Shopping}

Attitudes towards malls and mall shopping appear to vary between countries as well as regions. Such attitudes may be changing as millennials appear to be attracted to more interesting local stores in preference to malls, with a consensus that malls all have offerings that are similar to each other.

However, Narahari and Kuvad (2017) state that malls are still popular for several reasons. Amongst them is the atmosphere that can be improved by means of entertainment and food courts, giving the customer the opportunity to enjoy themselves beyond the obvious function of shopping. Add to this the phenomenon of the "one-stop shop" and the tangibility of the mall environment and one can understand how customers are drawn to locations such as these.

Jooste (2016) established that in South Africa, most Generation Y respondents shopped in a mall for a number of reasons:

- Escape activity - malls need to provide a wide variety of stores so that customers can fulfil the need to escape and make their own discoveries as they search to satisfy their needs.

- Aesthetic stimulation - the look and ambience of the mall should be pleasing to customers

- Flow - the mall should be designed in such a way that the customer is comfortable to move easily through the environment.

- Exploration - a shopping mall needs to provide a wide variety of offerings, along with access to social media through Wi-Fi etc.

- Role Playing - customers should be able to access a number of means in order to assist them to carry out the role in which they have approached the shopping mall.

- Social Interaction - many customers approach a mall with one of their main objectives being to be entertained. For this reason, many malls are incorporating large areas of entertainment activities such as cinemas, theme parks, bowling alleys and beauty salons.

- Convenience - this finding indicates that location of a mall is important with regard to both residence and public transport.

Gilboa, Vilnai-Yavetz and Chebat (2016) cite Lee et al. as stating in 2013 that the idea of understanding customer experience in a shopping mall is important in view of the increase in competition that malls have been experiencing from alternative formats such as more traditional shopping environments and online retailing.

\subsection{Global Shopping Mall Trends}

Olsen (2016) states that not all malls are failing and those that offer a better assortment are still popular and enjoying good sales, although the demise of a number of major anchors have damaged weaker malls as they restructure or depart. Cachinho (2014) states that "change has always shaped urban retail, and supply and demand have been its main architects. Consumers are constantly renewing their needs, wants and desires, changing their behaviours and lifestyles with direct consequences on shopping activities". The advent of more women working in the formal sector, an increase in exposure to the internet and social media and the elevated population in younger segments has resulted in higher incomes and hence a growth in purchasing power. However, a saturated market in the city centres has also served to encourage the spread of retail business to the outlying areas (Narahari \& Kuvad 2017).

Although these are global trends, Sohail (2015) stresses that there are significant differences between developed countries and developing countries regarding factors such as business environment and consumer behaviour. He therefore believes that it is necessary to study mall behaviours in different country settings to identify any possible nuances and differences due to the different developmental perspectives.

Thus, in the USA, a developed country, a number of shopping malls are either experiencing a loss in rentals or have even had to close their doors altogether (Sanburn 2017; Isidore 2017) Estimates were that in 2017 at least 8600 stores were expected to close down, a number of them previously popular anchors (Sanburn 2017). Rushe (2017) states that just 50\% of existing malls will still be operating in 2023, with Isidore (2017) citing Credit Suisse as suggesting that the figure could be closer to $25 \%$, which is still alarming. Malls that lose multiple anchor tenants are particularly vulnerable, as those losses can be a

www.jbrmr.com A Journal of the Academy of Business and Retail Management (ABRM) 
death knell for a property. Though several major mall owners have been able to fill these types of vacancies with sporting goods chains or entertainment concepts, the departure of multiple anchor tenants can often signal bigger problems for a property or market (Gustafson 2017).

A marginal increase has been noted in the development of shopping centres in Europe with about 37000 square metres of new space made available mainly in the UK, France and Finland in 2018. An additional 2.1 million square metres is under construction at present. However, this equates to approximately a $25 \%$ drop in new space over the last few years, as the shopping centre market reaches maturity (Coleman 2018).

In contrast to the developed countries, in India, a developing country, shopping malls are still springing up in many of the urban and semi-urban areas (Narahari and Kuvad 2017; Ratnakumari and Kumar 2017). In recent years, India has experienced changes in demography that are favourable towards development, including an increase in disposable income. Furthermore, the trend towards globalization, a positive economy and a change in Indian consumers' perceptions contribute towards an increase in growth of the formal retail sector. As a result of these positive changes the number of shopping malls has increased (Sadachar and Fiore 2018). Malls are offering Indian consumers an excellent shopping experience, along with providing the community with a central location where entertainment and leisure activities are on offer (Sadachar and Fiore 2018). Nevertheless, the Retailers Association of India notes that retail investors are still concerned about competitiveness, profitability and return on investment (Sadachar and Fiore 2018).

Another developing country, Saudi Arabia, has a booming retail sector, with malls accounting for about half the retail sales (Sohail 2015). Increasing income and changing lifestyles have resulted in a rapid growth of malls that are patronised by people who socialise and window-shop, in addition to actual shopping. However, according to Sohail (2015) consumer behaviour trends are changing, with gender roles beginning to overlap. Unfortunately most mall research is coming from developed nations, with a paucity of mall research from developing nations.

\subsection{Trends in Germany}

Shopping centres in Germany accounted for more than 15.4 million square meters in 2017. However, according to Lück and Jahn (2017), the downturn in the development of shopping centres in Germany exceeds that of the United States. Developers have also lost their appetite for malls and as a result, fewer new malls are opening (Kolf 2017). Over the past ten years, an average of ten new malls opened every year in Germany. According to Coleman (2018) shopping centre development has still continued in Germany with an excess of 200000 sq metres of additional shopping space in the pipeline. One of the reasons for this is to supplement the deterioration in existing shopping centres as they age, and existing space fails to meet current consumer requirements. Many shopping centres are more than 20 years old at this stage.

In addition, Lück and Jahn (2017) use the term "next stage of evolution" as they describe the damage that has been possibly wrought on the formal retail sector by on-line commerce. They argue that although shopping centres have been subjected to many challenges (one being on-line commerce), other pressures include it being a buyers' market, heightened competition and a failure in customer orientation due to poor positioning strategies. According to Kolf (2017), traditional shopping centres in Germany are experiencing a downturn in interest as customer traffic declines and sales decrease. Consequently, retailers state that turnover is insufficient and mall rentals are not favourable either. An average decline in sales of five percent in malls is viewed with alarm by many retailers (Kolf 2017).

Department stores have played an important role in the retail scenario for many decades. However, in recent years, a number of them have been observed to be struggling. Previously popular department store chain, Karstadt, is in trouble, as it tries to restructure in order to regain its stature in the marketplace. Department stores are rapidly losing ground to newer and more dynamic forms of retail such as online shopping, discount stores and shopping centres (The Decline of the Department Store, 2014). According to The Decline of the Department Store (2014), online retailing is the new market leader (as far as growth is concerned) and was making up nine percent of sales with a predicted growth of 17 percent in 2014 . 
Funder states in The Decline of the Department Store (2014) that retailers that wish to succeed will need to combine an online presence with shop frontage.

Kolf (2017) describes a demise in the traditional shopping centre in Germany, with one of the solutions (or contributors to the problem) being the development of multi-use developments where buildings are designed to accommodate a retail sector, along with housing, offices and restaurants. The new Dorotheen Quartier in Stuttgart is one of these, with only $25 \%$ of the floor area being dedicated to retail, similarly the Seedelhöfe in Ulm.

Lück and Jahn (2017) compared the scenario in Germany with that of the US and concluded that although the German marketplace has also reported less new openings of new malls, German purchasing power continues to grow. German malls report only a few situations where there are vacancies in malls and furthermore, no major shopping centre has had to close its doors. In contrast the US marketplace has exhibited declining consumption, a large-scale migration of consumers into more select highly populated areas and a high density of malls with intense competition. All of this has led to a dramatic decline in the shopping centre landscape.

\subsection{Trends in South Africa}

Amanda Stops, CEO of the South African Council of Shopping Centres states that the South African shopping centre industry features highly in the global marketplace. It is described as "one of the most developed and competitive shopping centre industries" in the world. According to Stops, South Africa is rated as having the sixth-highest number of shopping centres in the world (Naidoo 2018). In 2016, the number of shopping malls in South Africa numbered 1785. The largest shopping mall in Africa is the Menlyn Park centre that has recently (2016) spent R2 billion on expansion. Fourways Mall is busy with a multi-billion Rand redevelopment into a super-regional mall (Naidoo 2018).

Although large amounts of money have been invested in malls in South Africa, there are concerns that declines have been observed in the amount of traffic in some of the bigger malls. Busy mainly on the weekends, foot-traffic declines dramatically during the week (Tshandu 2017). This is mainly attributed to an economic downturn, along with many areas being saturated with malls. Furthermore, the failure to thrive of a number of major South African Chain stores (for example, Edgars and Stuttafords) has also been thought to contribute to the woes of shopping malls (Tshandu, 2017).

Although many years ahead of South Africa in terms of e-retailing, the question remains whether South African shopping centres will follow the patterns observed in the US?

\subsection{Suggested reasons for the Decline in Malls}

Ferreira and Paiva (2017) suggest that the decline of shopping malls could be explained by (1) the effect of innovation, (2) economics (retail and urban cycles and the way in which they interact and (3) the role of management. Furthermore, Ferreira and Paiva (2017) also note that, although there has been a demise in shopping malls in Lisbon, the decline seems to be mainly isolated towards three types of mall. These are small shopping galleries, neighbourhood shopping centres and convenience malls which are all older type malls, hence those that would be viewed as reaching the end of their life cycles. They are not able to compete with the newer and larger shopping centres which are centrally managed. Managers of smaller malls, as described above are not as skilled in coping with the environmental changes that malls are facing. Innovations are problematic for existing formats, as a new innovation that is viewed by the market as a more desirable alternative can easily entice customers to switch allegiance.

Atzberger (cited by Kolf, 2017) suggests that shoppers in Germany simply have too many retail options to choose from, resulting in malls experiencing lower numbers. Online shopping is also mentioned as one of the contributors to the problem. The escalation of online retail and e-commerce has resulted in a decline in both traffic and sales for retailers and malls, as customers seek out the best value that they can find (Narahari \& Kuvad 2017; Anselmsson 2016).

Lee and Lee (2018) highlights that the retail industry will experience incredible growth in sales that take place online, suggesting that online sales would constitute more than $14 \%$ of total retail sales by the year 2020. Millennials also cite a deterioration in service levels, making the internet a more desirable 
alternative (Olsen 2016). When shopping online, one can avoid dealing with crowds and unhelpful salespeople, shop at your own pace and call for support if you require it (Olsen 2016). Furthermore, customers often have access to better assortments to choose from online and better delivery (Calvo-Porral \& Lévy-Mangin 2019). However, it is highlighted that there is also a phenomenon of mall and online shopping being complementary, where research can be conducted online, but the shops are still attractive to provide the tangible advantages that customers seek. "Being able to feel, touch and try on products in a physical store" according to Elizabeth Zo (founder of Hero New York) in Olsen (2016).

The main reasons for growth in this phenomenon include the benefits of shopping at any time of the night or day, the saving in energy, money and time. In addition, the ability to gather and compare information on products is simplified. The benefit to customers of economies of scale experienced by retailers in malls is also attractive (Motwani, 2016; Al Debei, Akroush \& Ashouri, 2015; Ratnakumari \& Kumar 2017). In addition, customer reviews online have served to obviate the influence that retailers have over their potential customers (Narahari \& Kuvad 2017).

Internet World Stats (in Al Debei et al., 2015) states that global internet usage up to the year 2012 amounted to more than 2.41 billion individuals, which amounts to approximately 34 percent of the entire world population. The subsequent effect on business and the way in which it operates is massive, with particular impact on the retail sector (Al Debei et al., 2015).

In contrast, there is a perception that many brick and mortar stores are the same, as more, cheaper, fast-fashion outlets continue to open, and the availability of interesting and original products becomes scarcer (Olsen 2016). Sadachar and Fiore (2018) found that patronage could improve in a shopping mall if experiential value was one of the main concerns of management. Experiential value elements were described as elements that appeal to the customer's emotional, social and sensory states. This could be achieved through the offering of items that delight the customer, prestigious brands, exclusive events, ambience and contemporary design and décor. In addition, the offering of aesthetic and entertaining experiences can serve to augment the shopper's experience. In order to remain competitive, in particular with respect to online offerings, malls need to provide offerings that are superior to that of online stores.

\subsection{Strategies of Successful Malls}

The preceding discussion indicates that the owners and managers of shopping malls are being faced with increasing pressure to recreate themselves in a way that will increase traffic. According to Larsen et al. (2015), it has become important to identify the factors that serve to encourage or dissuade the flow of customers into a mall and, as a consequence, create sales. A number of authors have investigated the options of reviving elderly shopping malls, trying to identify the best options to do this. Anselmsson (2016) suggests that common features that attract customers to a mall include the right atmosphere, the correct retail mix, good access and services. Sadachar and Fiore (2018) found that one of the ways to draw more customers was to focus on experiential value providing "interactive, entertaining and elaborately designed retail environments". One of the ways of providing this is to highlight experiences that are both entertaining and aesthetic, leading to the provision of positive experiential value (Sadachar and Fiore 2018). According to Larsen et al. (2015), shopping centres and malls are still important components of the marketing channel, providing a crucial link for the customer to obtain goods and services. This is despite the increase in popularity of internet-based shopping.

Some of the ways of saving malls is for them to become 'epi-centres' of the community structure. The introduction of a number of international chains and discount stores as well as those that are exciting and offer technology-based products (for example, Apple) can all add interest to the mall. Anything new needs to be visible to passing traffic (Olsen 2016). Furthermore, when shoppers are able to enjoy a number of leisure activities beyond that of mere shopping, they become more motivated to spend time there (Calvo-Porall \& Lévy-Mangin 2017). Research conducted by Calvo-Porral and Lévy-Mangin (2017) indicated that good tenant variety, an attractive internal environment and an appealing leisure mix are all variables which serve to attract customers. Gilboa, Vilnai-Yavetz and Chebat (2016) found that customers that were responsive to the mall's social scape, i.e. being aware of the mall providing a location for social

www.jbrmr.com A Journal of the Academy of Business and Retail Management (ABRM) 
interaction and recreation, were more inclined to perceive that the mall equity (perceptions of mall awareness and image) was positive which could lead towards loyalty.

\subsection{To summarise}

From this overview of the literature, it is clear that there is a lot of discussion on the fate of malls in the popular press, and a lot on consumer behaviour in malls in the academic literature. However, as mentioned by Ferreira and Paiva (2017) there is a gap in the scientific knowledge on the demise of shopping malls and so they sought to investigate the reasons that underlie this phenomenon. This study, in Portugal, was one of the few academic studies on mall decline outside the USA. Considering the importance of malls in most countries and their recent development in developing nations, there is a need for greater understanding of mall decline in countries other than the USA, which underpins the rationale for this study.

\section{Research methodology}

To achieve the objectives, a quantitative, descriptive, cross sectional study was used, based on an emailed survey to a purchased, opt-in, online access panel.

\subsection{Respondents}

Since about two thirds of the South African population is urbanised, because shopping malls are located in urban areas and because the large distances in South Africa make it unfeasible for rural dwellers to shop at malls, we decided to select the South African Living Standards Measure (LSM) ${ }^{1}$ categories of 7 to 10 (predominantly urbanised) as the population. This is also more or less in line with Prinsloo's (2016) retail classification that specifies LSM 6-10 as the main customers of shopping malls. However, there has been a shift up the LSM categories as consumers become wealthier in South Africa, so it makes sense to focus only from LSM 7 and not to include LSM 6 (The mystery of the many shopping centres, 2014). For Germany, where these limitations of large rural populations and large distances do not exist, we accepted the study population as consumers aged $18+$.

To obtain a sample of the population, a list broker provided an online access panel and guaranteed the number of respondents set by the researchers as the sample size. The researchers determined quotas (i.e. gender, age and income for Germany and LSMs 7 - 10 for South Africa) to ensure that the countries' populations were represented. Although lower LSM customers are starting to be targeted by shopping malls in South Africa, this is a recent trend, so it makes sense to focus on the LSMs that have been targeted in the past as it is the past experiences that influence current perceptions (Malls are Broadening Appeal, 2018). Since this was a self-selected sample (i.e. list members chose whether to respond or not) the sampling method was non-probability. Assuming a 95\% confidence level, a variance of 1 and an allowed error of 0.1, a sample of 384 was deemed adequate for a very large population (Sekaran and Bougie, 2013). To allow for any unusable questionnaires, a sample of 800 (400 from each country) was required.

\subsection{Data collection}

The questionnaire was developed to answer the four issues reflected in the objectives of the study, namely attitudes to malls, trends in mall shopping, reasons for shopping less in malls and things malls can do to make them more attractive. These accounted for four of the sections in the questionnaire, with a fifth section being devoted to demographic data collection, namely descriptive measures of country, gender, age, habitation, education and household income.

To obtain measures for the issues to be researched, questions were developed from both academic and practitioner literature. In Section 1, to assess the respondents' attitudes towards shopping malls and shopping in these malls, articles by Cokayne, 2016; Ferreira and Paiva, 2017; Kiganda, 2016; Muller, 2017; Olsen, 2016; Rushe, 2017; Sanburn, 2017; SAPOA, 2017 and Tshandu, 2017 were used. To identify possible trends (increasing, static, declining) in shopping mall use, which was Section 2, we extracted questions

${ }^{1}$ Living Standard Measures is the most widely used segmentation method in South Africa. It splits the population into ten LSM groups, 1 (lowest) to 10 (highest), to segment a market according to criteria such as degree of urbanization and ownership of cars and major appliances. It thus integrates both socio-demographic factors and consumer product use (Living Standards Measure, 2017). 
from Anselmsson, 2016; Calvo-Porral et al., 2018; Gustafson, 2017; Larsen et al., 2015; Makgope, 2016; Muller, 2017; Tshandu, 2017 and Van Zyl, 2017.

Section 3 covered possible reasons for respondents not shopping as much in malls as they did a few years ago, being split into Internet reasons (from articles by Cokayne, 2016 Isidore, 2017; Lewis, 2014; Thompson, 2017), behavioural reasons (from articles by Badger, 2015; Cokayne, 2016; Gustafson, 2017; Lewis, 2014; Olsen, 2016 and Sanburn, 2017), economic reasons (from articles by Lewis, 2014; Lück and Jahn, 2017 and News24Wire. 2017), mall environment reasons (from articles by Anselmsson, 2016; Badger, 2015; Gustafson, 2017; Olsen, 2016; Rousseau and Venter, 2014 and Tshandu, 2017) and mall location reasons (from articles by Gustafson, 2017; Olsen, 2016 and Sanburn, 2017). Possible ways that shopping malls could improve their attractiveness to shoppers made up Section 4, with suggestions being identified from articles by Al, 2017; Kolf, 2017; Lewis, 2014; Lor, 2018; Lück and Jahn, 2017; Olsen, 2016; Rushe, 2017; Sanburn, 2017 and Tshandu, 2017.

Sections 1 to 4 were all structured as statements with response categories structured as 7-point Likert types scales with $1=$ strongly disagree through to $7=$ strongly agree. Finally, a live pilot test of the questionnaire was conducted with eighty consumers who matched the population criteria, which showed the questionnaire to be understandable and acceptable to the population.

The questionnaire was administered by e-mail to the potential respondents, who accessed the questionnaire by clicking on a URL link in the e-mail. The e-mail with the embedded link had been provided to the list broker who sent the mailing out. Comprehensive mailing reports were provided to prove that the mailing had taken place. When the respondents completed the questionnaire, clicking on the SUBMIT button sent the completed questionnaire to the researchers and not to the list broker.

\subsection{Data analysis}

Completed questionnaires were received by the researchers who did a quality check of the data using different cross tabulations, e.g. "Visit malls more often" but "spend less time and/or money" (Q. $1.1,1.2,1.3)$ and "I chase discounts" (2.3) and "my purchasing power has declined" (4.4). Where two or more answers did not fit logically, the relevant questionnaire (respondent) was deleted from the analysis. This resulted in a useable sample as shown in Table 1. Analysis was done using SPSS version 23.

\begin{tabular}{|l|l|l|}
\hline Country & Frequency & Percent \\
\hline South Africa & 403 & 49,2 \\
\hline Germany & 416 & 50,8 \\
\hline Total & 819 & 100,0 \\
\hline
\end{tabular}

Table 1: Useable sample

Thereafter univariate descriptive statistics, analysed by country and total, were calculated. Then using exploratory factor analysis, shown in Table 2, the dimensions identified from the literature review were checked for accuracy. The varimax rotated matrix provided a cumulative rotation sum of the squared loadings of $65.8 \%$ and showed that the dimensions "dependent variable", "general attitude", "location", "internet", "economic" and "environmental" as identified from the literature review are acceptable. The dimensions "behaviour" and "offer" did not show a clear acceptability. These two dimensions also showed the lowest values for Cronbach's Alpha - behaviour 0.53 and offer 0.37 - whereas the other dimensions showed Cronbach's Alpha values of 0.8 and higher.

The research questions were then assessed using means, tests of significance (independent $t$-tests and chi square as relevant) and multivariate regression. The evaluation of the requirement for the multivariate regression analysis shows mainly acceptable results:

Heteroscedasticity: Plot of standardized predicted values against standardized residuals only show very slight indicators for Heteroscedasticity

Multicollinearity: all between 0.54 and 0.90

Autocorrelation: Durban-Watson: 1.7

Normal-distributed residuals: histogram of residuals and P-. P.-Plot of standardized residuals show no indication for not normal-distributed residuals.

www.jbrmr.com A Journal of the Academy of Business and Retail Management (ABRM) 


\begin{tabular}{|c|c|c|c|c|c|c|c|c|c|}
\hline $\begin{array}{l}\text { Vari- } \\
\text { able }\end{array}$ & Questions & $\begin{array}{l}\text { Environ- } \\
\text { ment } \\
1 \\
\end{array}$ & $\begin{array}{l}\text { Change in } \\
\text { mall use } \\
2\end{array}$ & $\begin{array}{l}\text { Internet } \\
3 \\
\end{array}$ & 4 & $\begin{array}{l}\text { Economic } \\
\text { reasons } \\
5 \\
\end{array}$ & $\begin{array}{l}\text { General } \\
\text { attitude } \\
6\end{array}$ & 7 & $\begin{array}{l}\text { Loca-tion } \\
8 \\
\end{array}$ \\
\hline \multirow{3}{*}{$\begin{array}{l}\text { Change } \\
\text { in mall } \\
\text { use }\end{array}$} & Q7.1.1 Visit malls more often than I did 2-3 years ago. & -0.103 & 0.874 & 0.013 & 0.010 & 0.073 & -0.047 & 0.176 & 0.045 \\
\hline & Q7.1.2 Spend more time in malls than 2-3 years ago. & -0.071 & 0.879 & 0.065 & -0.012 & 0.094 & -0.072 & 0.175 & 0.073 \\
\hline & Q7.1.3 Spend more money in malls than 2-3 years ago. & -0.044 & 0.867 & 0.045 & 0.112 & 0.007 & -0.138 & -0.003 & 0.010 \\
\hline \multirow{3}{*}{$\begin{array}{l}\text { General } \\
\text { attitude }\end{array}$} & $\begin{array}{l}\text { Q7.1.4 Smaller, local, malls are more popular while larger regional } \\
\text { malls or "super malls" less popular. }\end{array}$ & 0.303 & -0.056 & -0.008 & 0.398 & -0.295 & 0.339 & 0.070 & -0.080 \\
\hline & Q7.1.7 Decline of mall shopping is inevitable. & 0.270 & -0.120 & 0.049 & 0.275 & -0.216 & 0.284 & 0.086 & -0.029 \\
\hline & Q7.2.7 We really do not need any more shopping malls. & 0.072 & -0.181 & 0.020 & 0.117 & 0.024 & 0.938 & -0.063 & 0.040 \\
\hline \multirow{3}{*}{ Offer } & Q7.2.1 Go to mall to shop, ie to buy groceries, clothes, etc & -0.078 & 0.394 & 0.017 & 0.243 & 0.509 & 0.020 & -0.250 & -0.020 \\
\hline & Q7.2.2 Go to mall to spend time, to eat, drink, see a movie & -0.042 & 0.315 & 0.093 & 0.050 & 0.021 & -0.020 & 0.872 & 0.043 \\
\hline & Q7.2.4 Avoid mall without mix of shops and products to satisfy me. & 0.094 & -0.015 & 0.041 & 0.716 & 0.073 & -0.063 & -0.071 & 0.117 \\
\hline \multirow[b]{2}{*}{$\begin{array}{l}\text { Loca- } \\
\text { tion }\end{array}$} & Q7.2.6 Do not choose mall to shop at just because it is closest. & 0.083 & 0.098 & 0.045 & 0.127 & 0.000 & 0.023 & 0.036 & 0.961 \\
\hline & $\begin{array}{l}\text { Q7.1.5 Since many people are moving back to living in the city centres, } \\
\text { shopping locally rather than at distant malls... }\end{array}$ & 0.179 & 0.121 & 0.009 & 0.029 & 0.002 & 0.003 & 0.102 & 0.568 \\
\hline \multirow{3}{*}{ Internet } & Q8.3.1 Spend more time shopping on-line than 2-3 years ago. & 0.057 & 0.111 & 0.899 & 0.064 & 0.069 & 0.010 & 0.036 & 0.006 \\
\hline & Q8.3.2 Spend more money shopping on-line than 2-3 years ago & 0.049 & 0.089 & 0.914 & 0.091 & 0.021 & 0.018 & -0.024 & 0.054 \\
\hline & Q8.3.3 Buy on-line, so visit bigger malls only occasionally & 0.262 & -0.107 & 0.780 & 0.070 & -0.045 & 0.001 & 0.091 & -0.010 \\
\hline \multirow{3}{*}{$\begin{array}{l}\text { Beha- } \\
\text { vioural }\end{array}$} & Q8.3.4 Young people meet socially online more than 2-3 yrs ago. & -0.065 & 0.113 & 0.257 & 0.397 & 0.179 & 0.094 & -0.083 & 0.021 \\
\hline & Q9.4.1 Gen X and Y shoppers prefer smaller, more intimate malls & 0.501 & 0.062 & 0.098 & 0.280 & -0.089 & 0.039 & 0.117 & -0.033 \\
\hline & Q9.4.2 Don't have time to get to mall and wander around shopping. & 0.673 & -0.144 & 0.108 & 0.040 & 0.077 & 0.031 & 0.024 & -0.090 \\
\hline \multirow{3}{*}{$\begin{array}{l}\text { Econ- } \\
\text { omic } \\
\text { reasons }\end{array}$} & Q7.2.3 Buyer habits changing, seek discounts, lower prices more & 0.121 & 0.152 & 0.110 & 0.329 & 0.647 & -0.068 & 0.155 & 0.036 \\
\hline & Q9.4.3 Visit malls less often to save money on transport. & 0.264 & -0.074 & 0.071 & 0.129 & 0.502 & -0.064 & 0.101 & 0.008 \\
\hline & Q9.4.4 Due to poor economy and buying power, I visit malls less & 0.603 & -0.160 & -0.080 & -0.005 & 0.585 & 0.033 & 0.044 & -0.069 \\
\hline \multirow{6}{*}{$\begin{array}{l}\text { Mall } \\
\text { environ- } \\
\text { ment }\end{array}$} & Q7.1.6 Malls are too crowded, too many people at peak times & 0.344 & -0.001 & 0.040 & 0.510 & 0.093 & 0.122 & -0.002 & 0.028 \\
\hline & Q7.2.5 Avoid mall that is poorly managed, maintained, not clean & 0.672 & -0.010 & 0.052 & -0.043 & 0.128 & 0.104 & 0.028 & 0.048 \\
\hline & Q9.4.5 Malls are not pleasant, social gathering places. & 0.638 & -0.172 & 0.085 & 0.014 & -0.172 & 0.270 & -0.322 & 0.080 \\
\hline & Q9.4.6 Malls are unpleasant, enclosed, anonymous, too big & 0.715 & -0.145 & 0.058 & -0.005 & -0.221 & 0.224 & -0.228 & 0.005 \\
\hline & Q9.4.7 Malls are not safe, with inefficient security, unsafe parking & 0.671 & 0.029 & 0.042 & 0.005 & 0.063 & -0.014 & 0.054 & 0.073 \\
\hline & Q9.4.8 Less investment in older malls, unmaintained and tatty. & 0.523 & 0.086 & 0.038 & 0.248 & 0.045 & -0.028 & -0.088 & 0.159 \\
\hline
\end{tabular}

Extraction Method: Principal Component Analysis. $\quad$ Rotation Method: Varimax with Kaiser Normalization. a. Rotation converged in 8 iterations 


\subsection{Validity and reliability}

Face and construct validity were achieved by a deconstruction, analysis and detailed discussion of the questionnaire's questions and response categories, in South Africa and Germany. Individual questions were matched to the dependent and independent variables to ensure the questionnaire assesses what we intend it to assess. Furthermore, a pilot test was conducted with eighty consumers who matched the population criteria. Quality and plausibility checks of the data proved acceptable, with the sample being reasonably representative of the two populations in terms of gender, age, monthly household net income and LSM levels (for South Africa).

Reliability was assessed via Cronbach's Coefficient Alpha, both in the pilot study and the final sample. A coefficient of 0.8 and higher was obtained for all the dimensions, with the exception of "behaviour" (0.53) and "offer" $(0,37)$. Since these latter two also did not show a clear allocation in the factor analysis, they were eliminated from further analysis.

\begin{tabular}{|l|l|l|l|l|l|l|l|}
\hline $\begin{array}{l}\text { Change in } \\
\text { mall use }\end{array}$ & Location & $\begin{array}{l}\text { Environ- } \\
\text { mental }\end{array}$ & Internet & Economic & $\begin{array}{l}\text { General } \\
\text { attitude }\end{array}$ & $\begin{array}{l}\text { Beha- } \\
\text { vior }\end{array}$ & Offer \\
\hline 0.882 & 0.882 & 0.873 & 0.856 & 0.843 & 0.841 & 0.530 & 0.370 \\
\hline
\end{tabular}

Table 3: Reliability - Cronbach's Coefficient Alpha

\subsection{Ethical issues}

A letter of information and consent was built into the questionnaire's opening page with a button to confirm that the respondent had full understanding and agreed to participate, making the questionnaire an opt-in survey. Anyone failing to click the opt-in button was not able to progress further with the questionnaire. Confidentiality and anonymity were ensured by not asking for any individual names.

\section{Results}

In this section, the profile of the sample is presented, followed by the descriptive statistics for each question, and finally the analysis and discussion of the four research questions.

\subsection{Demographic Profile of Respondents}

Table 4 reflects the demographic profile of the 819 useable responses, split by country, gender, age, where respondent lives, education, and household income.

Table 4 shows a reasonable distribution for both the developed and the developing countries across all demographic categories. However, the sample is not identical to the South African (developing country) population statistics - for example, the South African (developing country) sample shows a higher proportion of females (62\%) than the South African population. This can be explained by the fact that LSMs 7, 8 and 9 are biased towards females (Living Standards Measure, 2017) and by the probability that shopping is more often done by females, especially in developing countries. Docrat (2007) found females to account for 59\% of mall shoppers in South Africa and Sohail (2015) showed females to be more frequent shoppers in Saudi Arabia. Regarding the developed country, the German sample is representative of the population, since it was based on quotas predetermined according to the German population.

\begin{tabular}{|c|c|c|c|c|c|c|c|}
\hline \multirow[t]{2}{*}{ Dimension } & \multirow[t]{2}{*}{ Category } & \multicolumn{2}{|c|}{ Total } & \multicolumn{2}{|c|}{ South Africa } & \multicolumn{2}{|c|}{ Germany } \\
\hline & & f & $\%$ & f & $\%$ & f & $\%$ \\
\hline \multirow[t]{2}{*}{ Gender } & Female & 461 & 56.3 & 250 & 62.0 & 211 & 50.7 \\
\hline & Male & 358 & 43.7 & 153 & 38.0 & 205 & 49.3 \\
\hline \multirow[t]{5}{*}{ Age } & $18-24$ & 108 & 13.2 & 71 & 17.6 & 37 & 8.9 \\
\hline & $25-34$ & 220 & 26.9 & 158 & 39.2 & 62 & 14.9 \\
\hline & $35-49$ & 198 & 24.2 & 102 & 25.3 & 96 & 23.1 \\
\hline & $50-59$ & 11 & 14.0 & 32 & 7.9 & 83 & 20.0 \\
\hline & $60+$ & 178 & 21.7 & 40 & 9.9 & 138 & 33.2 \\
\hline \multirow[t]{4}{*}{ Habitation } & Rural (<5000 people) & 80 & 9.8 & 10 & 2.5 & 70 & 16.8 \\
\hline & Small town/village (5000-39999) & 186 & 22.7 & 69 & 17.1 & 117 & 28.1 \\
\hline & City/large town (40000-249 999) & 271 & 33.1 & 161 & 40.0 & 110 & 26.4 \\
\hline & Metro $(250000+)$ & 282 & 34.4 & 163 & 40.4 & 119 & 28.6 \\
\hline Education & None & 1 & 0.1 & 0 & 0.0 & 1 & 0.2 \\
\hline
\end{tabular}




\begin{tabular}{|l|l|l|l|l|l|l|l|}
\hline & Some or all primary completed & 105 & 12.8 & 0 & 0.0 & 105 & 25.2 \\
& Some high school & 53 & 6.5 & 15 & 3.7 & 38 & 9.1 \\
& Matric & 277 & 33.8 & 108 & 26.8 & 169 & 40.6 \\
& Intermediate between secondary level and & 138 & 16.8 & 90 & 22.3 & 48 & 11.5 \\
& university (e.g. technical training) & & & & & \\
& Technikon or University bachelor's degree & 221 & 27.0 & 173 & 42.9 & 48 & 11.5 \\
& Master's degree Doctorate or PhD & 24 & 2.9 & 17 & 4.2 & 7 & 1.7 \\
\hline Household & 0 - R8 000/ 0-€1300 & 160 & 19.5 & 70 & 17.4 & 90 & 21.6 \\
income & R8 001 - 18 000/€1300-2000 & 211 & 25.8 & 116 & 28.8 & 95 & 22.8 \\
& R18 001 - 37 000/€2001-3200 & 247 & 30.2 & 138 & 34.2 & 109 & 26.2 \\
& R37001 - 63 000/€3201-6000 & 144 & 17.6 & 46 & 11.4 & 98 & 23.6 \\
& More than R63000/€6000 & 57 & 7.0 & 33 & 8.2 & 24 & 5.8 \\
\hline Mall visit & Once or more per week & 317 & 38.7 & 179 & 44.4 & 138 & 33.2 \\
frequency & About twice per month & 238 & 29.1 & 133 & 33.0 & 105 & 25.2 \\
& About once per month & 132 & 16.1 & 65 & 15.9 & 68 & 16.3 \\
& Less often than once per month & 115 & 14.0 & 25 & 6.2 & 90 & 21.6 \\
& Never & 17 & 2.1 & 2 & 0.5 & 15 & 3.6 \\
\hline
\end{tabular}

Table 4: Demographic profile of respondents

Another interesting statistic from Table 4 is that $38.7 \%$ of all respondents (German and South African) visit a mall at least once a week, and $67.8 \%$ visit at least twice per month, indicating that the sample has a good coverage of mall shoppers, especially frequent mall shoppers. It is important to note that, in the developing country, South Africans visit more frequently $(44.4 \%$ once a week or more) than Germans do (33.2\%) in the developed country. This may be due to the easier availability of "high street" or non-mall shopping in Germany, and possibly in other developed countries.

\subsection{Research question 1: Attitudes towards malls and mall shopping}

Table 5 shows the results for individual statements referring to consumers' attitudes towards shopping centres/malls, their patronage of malls and possible reasons for changes in mall patronage.

\begin{tabular}{|c|c|c|c|c|c|c|c|c|}
\hline 1 & 2 & 3 & 4 & 5 & 6 & 7 & & \\
\hline \multirow{3}{*}{$\begin{array}{l}\text { Questions } \\
\text { Q7.1.4 Smaller, local, malls are more } \\
\text { popular while larger regional malls or } \\
\text { "super malls" are less popular }\end{array}$} & $\begin{array}{l}\text { Cou- } \\
\text { ntry }\end{array}$ & $\mathrm{N}$ & Mean & $\begin{array}{l}\text { Std. } \\
\text { Dev }\end{array}$ & $\begin{array}{l}\text { Total } \\
\text { mean }\end{array}$ & $\begin{array}{ll}\text { Sig } & 2 \\
\text { tail } & \end{array}$ & $\begin{array}{l}\text { Diff in } \\
\text { mean }\end{array}$ & difference \\
\hline & SA & 403 & 4.24 & 1.603 & \multirow[b]{2}{*}{4.28} & \multirow[b]{2}{*}{.427} & & \\
\hline & GER & 416 & 4.32 & 1.421 & & & & \\
\hline \multirow{2}{*}{$\begin{array}{l}\text { Q7.1.5 Since many are moving back to } \\
\text { living in the city, shopping locally rather } \\
\text { than at distant malls }\end{array}$} & SA & 403 & 5.01 & 1.473 & \multirow[b]{2}{*}{4.83} & \multirow[b]{2}{*}{.000} & \multirow[b]{2}{*}{0.368} & \multirow[b]{2}{*}{$\begin{array}{l}0.176 \\
0.580\end{array}$} \\
\hline & GER & 416 & 4.65 & 1.327 & & & & \\
\hline \multirow{2}{*}{$\begin{array}{l}\text { Q7.1.6 Malls are too crowded, too many } \\
\text { people at peak times }\end{array}$} & SA & 403 & 5.46 & 1.481 & \multirow{2}{*}{5.22} & \multirow{2}{*}{.000 } & \multirow{2}{*}{0.469} & 0.266 \\
\hline & GER & 416 & 4.99 & 1.470 & & & & \\
\hline \multirow{2}{*}{$\begin{array}{l}\text { Q7.1.7 Decline of mall shopping is } \\
\text { inevitable }\end{array}$} & SA & 403 & 4.01 & 1.528 & \multirow{2}{*}{4.08} & \multirow{2}{*}{139} & \multirow{2}{*}{ - } & \\
\hline & GER & 416 & 4.16 & 1.342 & & & & \\
\hline \multirow{2}{*}{$\begin{array}{l}\text { Q7.2.1 Go to mall to shop, i.e. to buy } \\
\text { groceries, clothes, etc. }\end{array}$} & SA & 403 & 5.64 & 1.415 & \multirow{2}{*}{5.22} & \multirow[t]{2}{*}{.000} & \multirow{2}{*}{0.813} & 0.605 \\
\hline & GER & 416 & 4.82 & 1.609 & & & & 1.021 \\
\hline \multirow{2}{*}{$\begin{array}{l}\text { Q7.2.2 Go to mall to spend time, to eat, } \\
\text { drink, see a movie }\end{array}$} & SA & 403 & 4.14 & 1.819 & \multirow{2}{*}{3.72} & \multirow[t]{2}{*}{.000} & \multirow{2}{*}{0.826} & 0.538 \\
\hline & GER & 416 & 3.31 & 1.724 & & & & 1.069 \\
\hline \multirow{2}{*}{$\begin{array}{l}\text { Q7.2.3 Buyer habits changing, seek } \\
\text { discounts, lower prices more }\end{array}$} & SA & 403 & 5.65 & 1.511 & \multirow{2}{*}{5.16} & \multirow[t]{2}{*}{.000} & \multirow{2}{*}{0.953} & \\
\hline & GER & 416 & 4.69 & 1.612 & & & & 1.167 \\
\hline \multirow{2}{*}{$\begin{array}{l}\text { Q7.2.4 Avoid mall without mix of shops } \\
\text { and products to satisfy me }\end{array}$} & SA & 403 & 5.38 & 1.485 & \multirow{2}{*}{5.04} & \multirow[t]{2}{*}{.000} & & 0.465 \\
\hline & GER & 416 & 4.70 & 1.543 & & & $0.6 / 3$ & 0.881 \\
\hline Q7.2.5 Avoid mall that is poorly & SA & 403 & 5.85 & 1.466 & 563 & .000 & 0433 & 0.234 \\
\hline managed, maintained, not clean & GER & 416 & 5.42 & 1.431 & 5.63 & & 0.433 & 0.632 \\
\hline Q7.2.6 Do not choose mall to shop at just & SA & 403 & 4.31 & 1.820 & & & & \\
\hline because it is closest & GER & 416 & 4.27 & 1.620 & 4.29 & .796 & - & \\
\hline Q7.2.7 We really do not need any more & SA & 403 & 4.04 & 1.926 & 4.41 & .000 & -0.72 & -0.970 \\
\hline shopping malls & GER & 416 & 4.76 & 1.721 & 4.41 & & $-0 . / 2$ & -0.469 \\
\hline
\end{tabular}




\begin{tabular}{|c|c|c|c|c|c|c|c|c|}
\hline \multirow{2}{*}{$\begin{array}{l}\text { Q8.3.1 Spend more time shopping on-line } \\
\text { than 2-3 years ago }\end{array}$} & SA & 403 & 4.65 & 1.913 & \multirow{2}{*}{4.74} & \multirow{2}{*}{.166} & \multirow[b]{2}{*}{ - } & \\
\hline & GER & 416 & 4.82 & 1.630 & & & & \\
\hline \multirow{2}{*}{$\begin{array}{l}\text { Q8.3.2 Spend more money shopping on- } \\
\text { line than 2-3 years ago }\end{array}$} & SA & 403 & 4.60 & 1.915 & \multirow{2}{*}{4.73} & \multirow{2}{*}{.044} & \multirow{2}{*}{-0.250} & \multirow{2}{*}{$\begin{array}{l}-0.49-- \\
0.07\end{array}$} \\
\hline & GER & 416 & 4.85 & 1.624 & & & & \\
\hline \multirow{2}{*}{$\begin{array}{l}\text { Q8.3.3 Buy on-line, so visit bigger malls } \\
\text { only occasionally }\end{array}$} & SA & 403 & 4.03 & 1.861 & \multirow{2}{*}{4.22} & \multirow{2}{*}{.003} & \multirow{2}{*}{-0.359} & $-0.598 \quad-$ \\
\hline & GER & 416 & 4.39 & 1.607 & & & & 0.121 \\
\hline \multirow{2}{*}{$\begin{array}{l}\text { Q8.3.4 Young people meet socially online } \\
\text { more than } 2-3 \text { yrs ago }\end{array}$} & SA & 403 & 5.70 & 1.299 & \multirow{2}{*}{5.81} & \multirow{2}{*}{.015} & \multirow{2}{*}{-0.209} & $-0,378$ \\
\hline & GER & 416 & 5.91 & 1.160 & & & & -0.40 \\
\hline \multirow{2}{*}{$\begin{array}{l}\text { Q9.4.1 Gen } X \text { and } Y \text { shoppers prefer } \\
\text { smaller, more intimate malls }\end{array}$} & SA & 403 & 4.33 & 1.504 & \multirow{2}{*}{4.16} & \multirow{2}{*}{.001} & \multirow{2}{*}{0.340} & 0.143 \\
\hline & GER & 416 & 3.99 & 1.365 & & & & 0.537 \\
\hline \multirow{2}{*}{$\begin{array}{l}\text { Q9.4.2 Don't have time to get to mall and } \\
\text { wander around shopping }\end{array}$} & SA & 403 & 3.99 & 1.685 & \multirow{2}{*}{3.91} & \multirow{2}{*}{.197} & \multirow{2}{*}{ - } & \\
\hline & GER & 416 & 3.83 & 1.659 & & & & \\
\hline \multirow{2}{*}{$\begin{array}{l}\text { Q9.4.3 Visit malls less often to save } \\
\text { money on transport }\end{array}$} & SA & 403 & 4.88 & 1.347 & \multirow{2}{*}{4.69} & \multirow{2}{*}{.000} & \multirow{2}{*}{0.364} & 0.174 \\
\hline & GER & 416 & 4.51 & 1.423 & & & & 0.554 \\
\hline \multirow{2}{*}{$\begin{array}{l}\text { Q9.4.4 Due to poor economy and buying } \\
\text { power, I visit malls less }\end{array}$} & SA & 403 & 4.81 & 1.600 & \multirow{2}{*}{4.25} & \multirow{2}{*}{.000} & & 0.876 \\
\hline & GER & 416 & 3.71 & 1.663 & & & 1.10 & 1.324 \\
\hline Q9.4.5 Malls are not pleasant, social & SA & 403 & 3.42 & 1.631 & 3.79 & 000 & -0.732 & $-0.951--$ \\
\hline gathering places & GER & 416 & 4.15 & 1.565 & 0.19 & .000 & -0.132 & 0.513 \\
\hline Q9.4.6 Malls are unpleasant, enclosed, & SA & 403 & 3.26 & 1.604 & 3.43 & 003 & $-0,33$ & -0.556 \\
\hline anonymous, too big & GER & 416 & 3.60 & 1.639 & 0.40 & .000 & -0.30 & -0.111 \\
\hline Q9.4.7 Malls are not safe, with inefficient & SA & 403 & 4.11 & 1.637 & & & & 0.257 \\
\hline security, unsafe parking & GER & 416 & 3.64 & 1.535 & 3.87 & .000 & 0.475 & 0.692 \\
\hline Q9.4.8 Less investment in older malls, & SA & 403 & 4.70 & 1.451 & 449 & 000 & 0414 & 0.221 \\
\hline unmaintained and tatty & GER & 416 & 4.29 & 1.362 & 4.49 & .000 & 0.414 & 0.607 \\
\hline$=$ highly significant & & & & & & & & \\
\hline
\end{tabular}

Table 5: Attitudes to, and patronage of, malls

The means shown in Table 5 are calculated from the responses to the 7-point Likert-type scaled questions $(1=$ strongly disagree to $7=$ strongly agree $)$. Those with values higher than 5 can be, on average, strongly agreeing with the statements, and thus of relevance to this study. Those with means for the total sample of more than 5, as shown in Column 6 of Table 5, are:

- $\quad$ Question 3.4 Young people meeting socially more online (5.81)

- $\quad$ Question 2.5 Avoiding poorly managed malls (5.63)

- $\quad$ Question 2.1 Visiting a mall mainly to shop (5.22)

- $\quad$ Question 1.6 Too crowded mall (5.22)

- $\quad$ Question 2.3 Rising importance of discounts (5.16) and

- $\quad$ Question 2.4 Avoiding mall with no good shop mix (5.02)

Interestingly, no questions were found with means of less than 3 - thus strong disagreement was not felt about the statements. Generally, the comparisons of the statements between the two countries were found to be highly significant, as is shown in Column 7, Table 5.

In order to compare the findings between the developing nation (South Africa) and the developed nation (Germany), Table 5 presents the size and significance of these differences between the two countries in Columns 7,8 and 9.

As shown in Table 5, the biggest, highly significant differences regarding attitudes to, and patronage of, shopping malls are:

South Africans visit malls less often $(4,81)$ because of their declining purchasing power, while Germans do not show a decline in visits (3,71); a difference of 1.10

South Africans show higher agreement with regard to chasing discounts (5.65) than Germans do (4.69); a difference: 0.953

South Africans slightly agree that they go to malls mainly to spend time, eat, drink and socialize (4.14), while Germans disagree with this reason for visiting malls (3.31); a difference of 0.826

South Africans agree much more strongly that they visit a mall mainly to shop for groceries, clothes and homewares (5.64) than Germans do (4.82); a difference of 0.813 , possibly because malls in Germany focus on clothes and special products, with groceries mostly being sold via standalone shops. 
South Africans disagree (3.42) that malls are not pleasant social gathering places, whereas Germans slightly agree (4.15) with this statement; a difference of -0.732

South Africans are indifferent or uncertain (4.04) regarding whether no new malls are needed, whereas Germans agree that no new malls are needed (4.76); a difference of -0.72

These findings indicate that the reasons for patronizing shopping malls, and the attitudes consumers have towards shopping malls, are significantly different between consumers from the developing country (South Africa) and consumers from the developed country (Germany).

\subsection{Research question 2: Trends of mall shopping}

The means shown in Table 6 are calculated from the responses to the 7-point Likert-type scaled questions $(1=$ strongly disagree to $7=$ strongly agree $)$ regarding changes in consumers' shopping activities in shopping malls. In order to compare the findings between the developing nation (South Africa) and the developed nation (Germany), Table 6 also presents an overview of the differences between the two countries.

\begin{tabular}{|c|c|c|c|c|c|c|c|}
\hline Question & $\begin{array}{l}\text { Coun- } \\
\text { try }\end{array}$ & $\mathrm{N}$ & Mean & $\begin{array}{l}\text { Std. } \\
\text { Dev }\end{array}$ & $\begin{array}{l}\text { Sig. (2- } \\
\text { tailed) }\end{array}$ & $\begin{array}{l}\text { Mean } \\
\text { diff }\end{array}$ & $\begin{array}{l}95 \% \text { conf } \\
\text { difference }\end{array}$ \\
\hline \multirow{2}{*}{$\begin{array}{l}\text { Q7.1.1. I visit shopping malls more } \\
\text { often now than I did 2-3 years ago. }\end{array}$} & SA & 403 & 4.42 & 1.905 & .000 & .633 & $.379-.887$ \\
\hline & GER & 416 & 3.79 & 1.799 & .000 & .633 & $.379-.888$ \\
\hline \multirow{2}{*}{$\begin{array}{l}\text { Q7.1.2. I spend more time in shopping } \\
\text { malls now than I did 2-3 years ago. }\end{array}$} & SA & 403 & 4.30 & 1.901 & .000 & .613 & $.360-.865$ \\
\hline & GER & 416 & 3.69 & 1.779 & .000 & .613 & $.360-.865$ \\
\hline \multirow{2}{*}{$\begin{array}{l}\text { Q7.1.3. I spend more money in } \\
\text { shopping malls now than I did } 2-3 \\
\text { years ago. }\end{array}$} & SA & 403 & 4.52 & 1.911 & .000 & .723 & $.470-.976$ \\
\hline & GER & 416 & 3.79 & 1.771 & .000 & .723 & $.470-.976$ \\
\hline \multirow{2}{*}{$\begin{array}{l}\text { Change in use of malls New variable- } \\
\text { recoded and averaged from } Q 1.1,1.2 \text { and } \\
1.3\end{array}$} & ZA & 403 & 3.59 & 1.688 & .000 & -.656 & $-.883--.429$ \\
\hline & GER & 416 & 4.24 & 1.620 & .000 & -.656 & $-.883--.429$ \\
\hline
\end{tabular}

Table 6: Trends in mall shopping - size and significance of differences between countries

The South Africans (the developing country) state that they visit shopping centres more often (4.42) than they did 2-3 years ago and that they spend more time (4.30) and money (4.52) than 2-3 years ago. In the developed country, it is the other way around. The Germans state that they visit less (3.79) and spend less time (3.69) and less money (3.79) than they did 2-3 years ago. Thus, in the developing country (South Africa) it appears as if there is a trend towards more mall shopping, whereas in the developed country (Germany) it appears as if there is a trend away from mall shopping.

\subsection{Research Question 3: Reasons for not shopping in malls as much as in the past}

To assess the model developed from the factor analysis, a multivariate regression analysis was conducted, but because the "decrease in mall use" was so small, it was not expected that the multivariate regression would show a high adjusted $\mathrm{r}^{2}$. In fact, an overall $\mathrm{r}^{2}$ of $26 \%$, a South African $\mathrm{r}^{2}$ of $18.3 \%$ and a German $\mathrm{r}^{2}$ of $35.4 \%$ were obtained. Since we were interested in reasons for NOT visiting malls as often, we also did regressions for those who disagree that they visit malls more often $(14 \%)$, for those who disagree that they spend more time in malls $(14.2 \%)$ and for those who disagree that they spend more money in malls $(16.7 \%)$. Clearly only the regression of the German (developed country) respondents reflecting a relatively high $\mathrm{r}^{2}$ of $35.4 \%$ is high enough to be of any meaningful use.

As shown in Research Question 2, the South Africans (developing country) do NOT say that they visit malls less or spend less time and money there. To better illustrate this, a new variable was created by recoding and merging the results of questions 1.1, 1.2 and 1.3 into a new dependent variable titled "change in use of malls in last 2-3 years". The mean value for the new merged variable "changes in use of malls in last 2-3 years" for the developing country (South Africa) was 3.59 with $1=$ increase of use, $4=$ no change in use, and $7=$ decrease in use of malls. Two thirds of respondents indicated that they agreed (including strongly and slightly) that they are using malls more frequently than 2-3 years ago. Since, according to the respondents' opinions, South Africans do NOT use malls less, it does not make sense to analyse why they use them less. 
For the developed country (Germany) the mean value for the new dependent dimension "change in use of malls in past 2-3 years" is 4.24. This means that the German respondents indicate a slight decrease in the variable "change in use of malls in past 2-3 years". This, together with the reasonable $\mathrm{r}^{2}$ from the regression analysis $(35.4 \%)$, led us to analyse this data further. Table 7 indicates the findings from the regression analysis of the developed country (German) respondents, namely the standardized BETA values and their significance.

\begin{tabular}{|l|c|l|}
\hline Reasons dimensions & Beta & Sig \\
\hline Offer in mall $(\mathrm{Q} 2.1,2.2,2.4)$ & $\mathbf{0 . 4 5 5}$ & $\mathbf{0 . 0 0 0}$ \\
\hline General attitude (Q 2.7,1.7,1.4) & $\mathbf{0 . 2 7 6}$ & $\mathbf{0 . 0 0 0}$ \\
\hline Location $(\mathrm{Q} 2.6,1,5)$ & $\mathbf{0 . 1 9 4}$ & $\mathbf{0 . 0 0 0}$ \\
\hline Mall environment $(\mathrm{Q} 4.5-4.8,2.5,1.6)$ & $\mathbf{0 . 1 6 2}$ & $\mathbf{0 . 0 0 2}$ \\
\hline Economic (Q 2.3, 4.3, 4.4) & $\mathbf{0 . 1 0 0}$ & $\mathbf{0 . 0 3 6}$ \\
\hline Behavioural (Q 4.1, 4.2, 3.4) & $\mathbf{0 . 0 9 3}$ & 0.062 \\
\hline Internet (Q 3.1 - 3.3) & $\mathbf{0 . 0 7 2}$ & 0.066 \\
\hline
\end{tabular}

Table 7: Regression analysis - reasons for less use of malls by German respondents

Key result from the multivariate regression is the $\mathrm{r}^{2}$ of $35.4 \%$, which indicates that the independent dimensions (reasons in Table 7) explain $35.4 \%$ of the changes in the use of malls in the last 2-3 years by German (developed country) respondents. The 'offer in mall' dimension (0.455) is the most important influencing dimension and around 1.7 times more important than the 'general attitude' (0.276), which is second most important. The 'general attitude' dimension (0.276) is 1.4 times more important for explaining the slight state decrease than dimension number 3 , the 'location' reason (0.194). 'Mall environment' reasons (0.162) is the fourth most important dimension. All the four mentioned dimensions are highly significant at $p<.001$ as influencing factors for the decrease in use of shopping malls. 'Economic' reasons show an importance of only 0.1 and is significant, whereas the importance of 'behavioural' reasons (0.09) and 'Internet' reasons (0.07) are very low and are not significant at even $\mathrm{p}=.05$.

\subsection{Research question 4: Recommendations to encourage mall shopping}

Based on questions 5.1 to 5.7, respondents provided their opinions on what can be done by shopping malls to improve their attractiveness to shoppers and thus to encourage consumers to visit more often, spend more time in the malls and to spend more money in malls. Table 8 indicates the means, mean differences and their significance.

\begin{tabular}{|c|c|c|c|c|c|c|c|}
\hline Question & Country & $\mathrm{N}$ & Mean & $\begin{array}{l}\text { Std. } \\
\text { Dev }\end{array}$ & $\begin{array}{l}\text { Sig } 2 \\
\text { tailed }\end{array}$ & $\begin{array}{l}\text { Mean } \\
\text { Diff }\end{array}$ & $\begin{array}{l}95 \% \text { conf } \\
\text { difference }\end{array}$ \\
\hline \multirow{2}{*}{$\begin{array}{l}\text { Q10.5.1 Malls should be converted } \\
\text { into "lively, attractive quarters", or } \\
\text { "lifestyle village" type environments. }\end{array}$} & $\mathrm{ZA}$ & 403 & 4.88 & 1.571 & .335 & .097 & $-.100-.295$ \\
\hline & GER & 416 & 4.78 & 1.303 & .336 & .097 & $-.101-.296$ \\
\hline \multirow{2}{*}{$\begin{array}{l}\text { Q10.5.2 Malls should convert to } \\
\text { mixed-use, with offices, colleges, } \\
\text { apartments in addition to shopping } \\
\text { and entertainment. }\end{array}$} & $\mathrm{ZA}$ & 403 & 4.15 & 1.810 & .038 & .247 & $.014-.481$ \\
\hline & GER & 416 & 3.90 & 1.586 & .038 & .247 & $.014-.481$ \\
\hline \multirow{2}{*}{$\begin{array}{l}\text { Q10.5.3 Malls should concentrate on } \\
\text { specialist shops that stock products } \\
\text { or brands that are only available } \\
\text { there. }\end{array}$} & $\mathrm{ZA}$ & 403 & 4.43 & 1.631 & .506 & -.071 & $-.279-.137$ \\
\hline & GER & 416 & 4.50 & 1.395 & .507 & -.071 & $-.279-.138$ \\
\hline \multirow{2}{*}{$\begin{array}{l}\text { Q10.5.4 Malls should make sure to } \\
\text { have interesting entertainment, like a } \\
\text { comedy club, museums, sports } \\
\text { studios, cafes, etc. }\end{array}$} & $\mathrm{ZA}$ & 403 & 5.61 & 1.314 & .000 & .863 & $.676-1.050$ \\
\hline & GER & 416 & 4.75 & 1.413 & .000 & .863 & $.676-1.050$ \\
\hline \multirow{2}{*}{$\begin{array}{l}\text { Q10.5.5 Going to a mall must give } \\
\text { you an experience you don't get } \\
\text { anywhere else. }\end{array}$} & $\mathrm{ZA}$ & 403 & 5.60 & 1.257 & .000 & .814 & $.627-1.001$ \\
\hline & GER & 416 & 4.78 & 1.460 & .000 & .814 & $.628-1.001$ \\
\hline \multirow{2}{*}{$\begin{array}{l}\text { Q10.5.6 Malls should have a clear } \\
\text { identity, appearance and orientation } \\
\text { that appeals to their customers. }\end{array}$} & $\mathrm{ZA}$ & 403 & 5.82 & 1.005 & .000 & .516 & $.370-.662$ \\
\hline & GER & 416 & 5.30 & 1.117 & .000 & .516 & $.370-.662$ \\
\hline
\end{tabular}




\begin{tabular}{|l|l|l|l|l|l|l|l|}
\hline Q10.5.7 Malls should integrate into & ZA & 403 & 5.64 & 1.168 & .000 & .397 & $.236-.559$ \\
\cline { 2 - 8 } \\
$\begin{array}{l}\text { their communities, help to educate, } \\
\text { inform, and engage consumers and } \\
\text { act for the good of.... }\end{array}$ & GER & 416 & 5.25 & 1.191 & .000 & .397 & $.236-.559$ \\
\hline
\end{tabular}

\section{Table 8: Ways to improve mall attraction}

There are recommendations that are common to both countries. It is clear that in both countries there are strong feelings that the malls should sharpen their identity (5.56) and integrate more into the community (5.44). Weaker recommendations include strengthening the unique experience of visiting a mall (5.18), improving the entertainment provided (5.17) and being a lively attractive quarter (4.83). There seems to be almost no need to concentrate on including specialist shops (4.47) or to convert malls to a mixed used area with offices, apartments etc., as has been happening in the USA.

However, these results also show that there are many differences between the two countries in terms of what respondents think malls should do to improve their attractiveness to consumers. The biggest, and highly significant, differences are about the improvement of entertainment $(95 \%$ confidence interval $0.76-1.05$ ) and to providing an experience not found elsewhere (95\% confidence interval 0.628 - 1.001). Both recommendations are stronger in South Africa (the developing country), which is probably because, in Germany (the developed country), malls are not usually seen as places of entertainment but mainly for shopping (and maybe eating out while shopping).

Smaller, but still highly significant, differences exist regarding malls needing to have a clear identity that appeals to their customers $(95 \%$ confidence interval $0.370-0.662)$ and needing to integrate into their communities (95\% confidence interval $0.236-0.559)$. Both recommendations are again stronger in the developing country (South Africa).

These differences in the recommendations made by the respondents from the two countries might be explained by the relative importance of shopping malls in Germany (developed country) and South Africa (developing country). There is a highly significant difference in the frequency with which South Africans and Germans visit shopping malls. Of the South African respondents, $44 \%$ visit a shopping centre once or more per week and $33 \%$ visit about twice a month, whereas the corresponding figures are significantly lower for Germany (33\% and $25 \%$ respectively). Clearly, shopping malls play a more important role in the daily life of South Africans than they do in the life of Germans. This therefore makes sense of the greater importance that the South African respondents placed on the recommendations they made.

\section{Discussion and conclusion}

From the discussion on the Research questions, it can be seen that there are significant differences between the South African and German respondents. South African patronage of malls is increasing, and they are spending more money and spending more time in malls than they did 2 to 3 years ago. Those respondents who are visiting less frequently are doing so due to their declining purchasing power, i.e. an economic reason. For the German respondents, they are visiting slightly less often and spending slightly less time and money.

This trend towards mall shopping by South Africans and away from mall shopping by Germans is reflected in their differing attitudes. Since South Africans are experiencing declining purchasing power and are chasing discounts and lower prices, they are more positive towards malls as places that they can get their declining funds to stretch further. Furthermore, they still see malls as places of entertainment (eating, socialising, movies) and places to shop for the full range of products (e.g. groceries, clothes, homeware, etc.). Germans on the other hand, do not see malls as places of entertainment, but as places to buy a limited range of products (e.g. clothes and specialised products), since groceries tend to be bought from standalone shops.

Overall South Africans have favourable attitudes about malls as pleasant, social gathering places, whereas Germans tend to hold slightly unfavourable attitudes towards malls and feel that there is no need for more malls.

In order to assess the reasons for a decrease in mall use, the new variable "change in use of malls in last 2-3 years" indicates that, on average, there has been no decline in mall use by South Africans. In fact, many are using malls more frequently. Therefore, it does not make sense to discuss reasons for decreased use. With regard to the German respondents, however, a slight decrease in mall use was reported. The 'product', 'general attitude', 'location' and 'mall environment' were all 
significant reasons for declining mall use, but the 'offer' reason was the strongest, namely reason for visiting (shopping, entertainment, etc.) and the mix of shops and products available. Clearly malls are no longer satisfying German shopping needs. An interesting fact is that neither in Germany nor in South Africa was increasing internet purchasing given as a significant reason for declining mall use.

The respondents from both countries felt that malls could be improved, and would be more attractive to customers, by improving their identities and by integrating more with their communities. Although significant for both countries, these recommendations were more strongly held by the South Africans. However, the main difference in the two sets of respondents was with regard to providing better entertainment and unique experiences. These recommendations were much stronger from South Africans than Germans.

In conclusion, we can see that shopping malls are still popular in South Africa, and the South African retailing environment can probably continue to host more shopping malls in the future, provided they address the needs of the South African consumer. In Germany, however, it appears as if the shopping mall may have run its course, with mall growth stagnant and little opportunity for further mall development.

\section{Limitations and direction for future research}

As with all research, there are some limitations relative to our study. First, our results are limited to Germany and South Africa. Although the German sample was representative of the German population, the South African sample included only LSMs 7 to 10, and so generalizability of the results is limited. Although LSMs 7-10 make up the bulk of mall shoppers, this is changing, with many lower LSM occupants becoming wealthier and moving to higher LSMs. In addition, lower LSM occupants have started patronising new malls in the previously 'black' areas. Therefore, research into LSMs 1-6 is needed.

Second, since relatively few South Africans were found who are using malls less, future research should attempt to identify a larger sample of such potential respondents in order to obtain a sample large enough to adequately identify the reasons why these types of shoppers are moving away from shopping in malls.

Third, since the regression analysis of the reasons for declining mall use explained only a small percentage of variation in mall use, a qualitative study needs to be conducted to try to identify other possible reasons - ones that may not have been identified in extant literature.

Fourth, as far as these reasons for the importance of the different dimensions are concerned, hypotheses could be formulated that can be the starting point for further research. As far as the offer variable is concerned, the impact of the offer of internet shops on attitudes to shopping malls should be further researched.

Finally, further research could be carried out into each of the factors that influence consumers' attitudes towards malls and shopping in malls. It would be beneficial to obtain more in-depth understanding of how economic factors, shop and product mix, location, Internet shopping and mall environment influence attitudes to malls and mall shopping.

\section{References}

Al, S. (2017). The Mall Isn't Dead, Its Just Changing. The Conversation. May 16. Available: http://theconversation.com/the-mall-isnt-dead-its-just-changing-72237.

Al Debei, M.M., Akroush, M.N. \& Ashouri, M.I. (2015). Consumer attitudes towards online shopping. The effects of trust, perceived benefits and perceived web quality. Internet Research, 25(5), 707-733.

Anselmsson, J. (2016). Effects of shopping Centre re-investments and improvements on sales and visit growth. Journal of Retailing and Consumer Service, 32, 139-150.

Badger, E. (2015). Why no one likes indoor malls anymore. The Washington Post, 6 January. Available: https://www.washingtonpost.com/news/wonk/wp/2015/01/06/why-no-one-likes-indoor-malls-anymore/?noredirect $=$ on\&utm_term $=$. b15da10ef59d

Cachinho, H. (2014). Consumerscapes and the resilience assessment of urban retail systems. Cities, 36, 131-144.

Calvo-Porral, C. \& Lévy-Mangin, J. (2018). Pull factors of the shopping malls: an empirical study. International Journal of Retail and Distribution Management, 46(2), 110-124.

Cokayne, R. (2016). SA sees decline in new malls - Accelerate. Business Report, 28 June. Available: https://www.iol.co.za/business-report/economy/sa-sees-decline-in-new-malls-accelerate-2039200. 
Coleman, R. 2018. Europe's Shopping Centre Market is reaching maturity. Cushman and Wakefield. July 2018. Available: http://cushmanwakefield.co.uk/en-gb/news/2018/10/europes-shopping-centre-market-isreaching-maturity

Docrat, S.H. (2007). An investigation of shopping centres as situational influences on consumer behaviour in the greater Durban area. M.Com: Management dissertation, University of KwaZulu-Natal, Durban, South Africa.

Ferreira, D. \& Paiva, D. (2017). The death and life of shopping malls: an empirical investigation on the dead malls in Greater Lisbon. The International Review of Retail, Distribution and Consumer Research, 27(4), 317-333.

Gilboa, S., Vilnai-Yavetz, I. \& Chebat, J.C. (2016). Capturing the multiple facets of mall experience: Developing and validating a scale. Journal of Consumer Behaviour, 15, 48-59.

Gustafson, K. (2017). While you've been paying attention to failing malls, these shopping centres are thriving. CNBC - Retail, 26 January. Available: https://www.cnbc.com/2017/01/26/why-these-malls-arethriving-while-others-die.html.

Guimarães, P.P.C. (2019). Shopping Centres in Decline: analysis of demalling in Lisbon. Cities, 87, 21-29.

Isidore, C. (2017). Malls are doomed: 25\% will be gone in 5 years. 2 June. @CNNMoney. Available: https://money.cnn.com/2017/06/02/news/economy/doomed-malls/index.html

Jooste, H. (2016). Mall shopping motivations among South African black Generation Y students. MCom: Marketing Management dissertation, North-West University, Vanderbijlpark, South Africa.

Kiganda, A. (2016). Construction of Shopping malls in South Africa declines. Construction Review Online, 30 Sep. Available: https://constructionreviewonline.com/2016/07/development-of-shopping-malls-in-southafrica-declines/.

Kolf, F. (2017). No more Mall Talk. Handelsblatt Global. Available: https://global.handelsblatt.com/companies/no-more-mall-talk-772764.

Kuroski, J. (2015). Media of Day: Aside from Black Friday, Malls Are Dying-And Not for the Reason You're Thinking. ATI - All That Is Interesting, 27 November. Available: http://allthatsinteresting.com/deadmalls.

Kushwaha, T., Ubeja, S. \& Chatterjee, A.S. (2017). Factors Influencing Selection of Shopping Malls: An exploratory study of Consumer Perception. Vision, 21(3), 274-283.

Larsen, V., Shelton, R. \& Wright, N.D. (2015). Shopping Center Attitudes: An Empirical test of predictive attributes. International Academy of Marketing Studies Journal, 19(2), 93-123.

Lee, J. \& Lee, Y.L. (2019). Does online shopping make consumers feel better? Exploring online retail therapy effects on consumers' attitudes towards online shopping malls. Asia Pacific Journal of Marketing and Logistics, https:/ / doi.org/10.1108/ APJML-06-2018-0210.

Lewis, R. (2014). Along with the Internet, Here Are 3 Other Culprits for Dying Malls. Huffpost, 11 July. Available: https://www.huffingtonpost.com/robin-lewis/malls-are-the-newanchors_b_5545761.html?utm_hp_ref=tw.

Living Standards Measure. (2017). South African Audience Research Foundation. Available: http://www.saarf.co.za/lsm/lsms.asp

Lor, C. (2018). \#BizTrends2018: Six trends shaping the shopping mall experience. Bizcommunity Retail News, 8 January. Available: http://www.bizcommunity.com/Article/196/160/171533.html .

Lück, M.F. \& Jahn, M. (2017). Are Malls in Germany also facing death? Across: The European Real Estate Magazine, Sep 29. Available: https://www.across-magazine.com/malls-germany-also-facing-death/.

Makgopa, S. (2016). Determining consumers' reasons for visiting shopping malls. Innovative Marketing, 12(2), 2227.

Malls are Broadening Appeal. (2018). Independent on Saturday, 9 April. Available: https://www.thdev.co.za/2018/04/malls-are-broadening-appeal/

Motwani, B. (2016). Prediction of Buying Intention for Online Shopping: An Empirical Study. The IUP Journal of Marketing Management, XV (4), 7-30

Muller, J. (2017). Empty malls hurt property investors. Financial Mail, 15 March. Available: https://www.businesslive.co.za/fm/money-and-investing/2017-03-10-empty-malls-hurt-propertyinvestors/.

Naidoo, S. (2018). Mall Brawl: Gateway grows as millions pour into new centres. Business Times. Sunday Times, 15 July.

Narahari, A.C. \& Kuvad, D. (2017). Customer Behaviour towards Shopping Malls - A Study in Bhavnagar (Gujurat State, India). International Journal of Advance Research and Innovative Ideas in Education, 3(2), 211223.

News24Wire. (2017). Sharp decline in shopping mall foot traffic in SA. Business Tech, 7 September. Available: https:/ / businesstech.co.za/news/business/197192/sharp-decline-in-shopping-mall-foot-traffic-in-sa/.

Olsen, L. (2016). Mall Malaise. Earnshaws, 1 June. Available: https://issuu.com/symphonypublishing/docs/earnshaws_june_2016 
Peterson, H. (2017). The retail apocalypse has officially descended on America. Business Insider, 21 March. Available: http://www.businessinsider.com/the-retail-apocalypse-has-officially-descended-on-america2017-3?IR=T

Prinsloo, D.A. (2016). Major retail types, classification and the hierarchy of retail facilities in South Africa. South African Council of Shopping Centres, September. Available: http://urbanstudies.co.za/wpcontent/uploads/2016/11/Classification-2016.pdf

Prinsloo, D.A. (2018). SA Shopping Centre Benchmarks 1998-2018 a trillion rand and fierce competition, South African Council of Shopping Centres, April. Available: https://www.urbanstudies.co.za/wpcontent/uploads/2018/05/Urban-Studies-report-Shopping-Centre-benchmarks2.pdf.

Ratnakumari, K.A. \& Kumar, B.P. (2017). Determinants of Buying Behaviour in Shopping Malls: A study of malls in Cochin City. International Journal of Humanities and Social Science Invention, 6(1), 2319-7714

Retail Trends: A Look at South Africa \& Others. (2017). Ebony and Ivory Marketing Promotions (Pty) Ltd. Available: https://www.ebonyivory.co.za/wp-content/uploads/EI-4752-Pivotal-Retail-Trends-ReportD2_small-1.pdf

Rousseau, G.G. \& Venter, D.J.L. (2014). Mall shopping preferences and patronage of mature shoppers. SA Journal of Industrial Psychology/SA Tydskrif vir Bedryfsielkunde, 40(1), Art. \#1175, 12 pages.

Rushe, D. (2017). Big, bold... and broken. Is the US shopping mall in a fatal decline? The Observer, 23 July. Available: https://www.theguardian.com/us-news/2017/jul/22/mall-of-america-minnesota-retailanniversary .

SACSC. (2018). Research reveals SA has more than 23 million square metres of retail space. Retailer News, 31 July. Available: http://www.fastmoving.co.za/news/retailer-news-16/research-reveals-sa-has-more-than-23million-square-metres-of-retail-space-12117

SAPOA. (2017). Research: Retail Trends Report. Available: http://www.sapoa.org.za/media/1170/2017-marchretail-trends-report-for-q4-period-ending-december-2016.pdf.

Sadachar, A. \& Fiore, A.M. (2018). The path to mall patronage intentions is paved with 4E-based experiential value for Indian consumers. International Journal of Retail and Distribution Management, 46(5), 442-465.

Sanburn, J. (2017). Why the Death of Malls Is About More Than Shopping? July 20. Available: http://time.com/4865957/death-and-life-shopping-mall/.

Sekaran, U. \& Bougie, R. (2013). Research Methods for Business: A Skill-building Approach. 6th ed. Chichester: Wiley.

Sohail, M.S. (2015). Gender differences in mall shopping: a study of shopping behaviour of an emerging nation. Journal of Marketing and Consumer Behaviour in Emerging Markets, 1(1), 36-46.

South Africa: Urbanization from 2007 to 2017. (2019). Statista. Available: https://www.statista.com/statistics/455931/urbanization-in-south-africa/

The Decline of the Department Store. (2014). DW (Deutsche Welle). Available: https://www.dw.com/en/thedecline-of-the-department-store/a-18013142.

The mystery of the many shopping centres. (2014). Mail \& Guardian, 23 May. Available: https:/ / mg.co.za/article/2014-08-06-the-mystery-of-the-many-shopping-centres-explained

Thompson, D. (2017). What in the World Is Causing the Retail Meltdown of 2017? The Atlantic, 19 April. Available: https://www.theatlantic.com/business/archive/2017/04/retail-meltdown-of-2017/522384/

Tshandu, P.V. (2017). Uncertain future for shopping malls. Business Live, 4 June. https://www.businesslive.co.za/bt/business-and-economy/2017-06-04-uncertain-future-for-shoppingmalls/

Van Zyl, G. (2017). SA needs fewer shopping malls and more local markets. Biznews, 15 August. Available: https://www.biznews.com/thought-leaders/2017/08/15/monopolies-shopping-malls-local-markets/ 